\title{
BOVINE CORONAVIRUS NUCLEOCAPSID PROTEIN PROCESSING AND ASSEMBLY
}

\author{
Brenda G. Hogue \\ Department of Microbiology and Immunology and Division of Molecular \\ Virology \\ Baylor College of Medicine \\ Houston, Texas
}

\begin{abstract}
The coronavirus nucleocapsid protein $(\mathrm{N})$ encapsidates the genomic RNA to form a helical nucleocapsid. The requirements for coronavirus nucleocapsid assembly are being studied. Two forms $(\sim 50 \mathrm{kDa}$ and $55 \mathrm{kDa})$ of the bovine coronavirus $(\mathrm{BCV}) \mathrm{N}$ protein were detected in infected cells. However, only one form, a $50 \mathrm{kDa}$ species, was detected in extracellular virions. After treatment with calf intestinal alkaline phosphatase (CIAP), the $55 \mathrm{kDa}$ intracellular form increased in mobility to comigrate with the $50 \mathrm{kDa}$ form; whereas, the $50 \mathrm{kDa}$ intracellular species and $\mathrm{N}$ from extracellular virions was not sensitive to CIAP treatment. The data indicate that specificity exists with regard to assembly of $\mathrm{N}$ into the mature virion. The data suggests that processing of $\mathrm{N}$ may take place during assembly of either nucleocapsids or virions and that the processing may be a dephosphorylation event.
\end{abstract}

\section{INTRODUCTION}

The coronavirus nucleocapsid protein is a multifunctional protein. It is a major virion structural protein that interacts with the genomic RNA to form a helical nucleocapsid '. In addition, the protein is also involved in viral replication and pathogenesis. $\mathrm{N}$ interacts with RNA sequences contained within the leader RNA found at the 5' ends of both the genomic and subgenomic mRNAs and it has been suggested that this interaction may be involved in viral transcription ${ }^{2}$. The protein is also important with regard to viral pathogenesis ${ }^{3,4}$.

The first step in the assembly of the coronavirus particle most likely involves a specific interaction between the N protein and the genomic RNA. The exact requirements for this initial step are not fully understood. The BCV N protein, like other coronavirus $\mathrm{N}$ proteins, is phosphorylated ${ }^{5}$. It is generally hypothesized that phosphorylation plays a role in the interaction of $\mathrm{N}$ and RNA and therefore, plays an important role in assembly. 
In the present study, analysis of the requirements for the $\mathrm{N}$ protein to be assembled into virions has been initiated. Two forms of $\mathrm{N}$ were detected in $\mathrm{BCV}$ infected cells. Both forms were phosphorylated. Only one form of $\mathrm{N}$ was detected in extracellular virions. Surprisingly, the extracellular virion $\mathrm{N}$ comigrated with the faster migrating $(50 \mathrm{kDa})$ intracellular form.

\section{MATERIALS AND METHODS}

HCT (HRT-18) cells and BHK cells (both from ATCC) were infected with BCV at an MOI of 5. Subconfluent cells in $60 \mathrm{~mm}$ plates were infected at $24 \mathrm{hpi}$. For ${ }^{32} \mathrm{P}$ labeling, cells were rinsed with phosphate free medium and then labeled with $50 \mu \mathrm{Ci}^{32} \mathrm{P}$ orthophosphate in phosphate free medium supplemented with 10\% normal DMEM and 10\% dialyzed fetal calf serum. For methionine labeling, infected cells were labeled with $100 \mu \mathrm{Ci}$ EXPRE ${ }^{35} \mathrm{~S}^{35} \mathrm{~S}$ label (NEN) and chased in medium containing an excess of methionine and cysteine. At the end of labeling, the medium was removed from the cells, clarified and extracellular virus pelleted at $35 \mathrm{~K} \mathrm{rpm}$ for $3 \mathrm{hrs}$ using an SW50.1 rotor. Cells were lysed and the cytoplasmic fraction collected. Virion pellets were resuspended in lysis buffer and both cell and virion lysates were precleared by incubating with protein A Sepharose for $1 \mathrm{hr}$. Precleared lysates were immunoprecipitated with an anti-BCV polyclonal antibody. Immune complexes were recovered by incubating with protein A Sepharose for $1 \mathrm{hr}$, eluted in 2X PAGE sample buffer and analyzed by SDS-PAGE. The ${ }^{32} \mathrm{P}$ labeled Sepharose-immune complex pellets were washed, resuspended in buffer without detergent and divided into three aliquots. One third of each immunoprecipitation was treated with either 40 units/ml RNase or 23 units of calf intestinal alkaline phosphatase for $30 \mathrm{~min}$ at $37^{\circ} \mathrm{C}$. One third was treated in the same way except without RNase or CIAP. After digestion, Sepharose-immune complexes were pelleted in a microfuge and eluted with 2X PAGE sample buffer and analyzed SDS-PAGE.

\section{RESULTS}

\section{Comparison of Intracellular and Extracellular Virions $\mathbf{N}$}

The BCV N protein, like other coronavirus $\mathrm{N}$ proteins, is phosphorylated ${ }^{5}$. As studies have been initiated on the assembly of coronaviruses we noticed a difference in the migration of the $\mathrm{N}$ protein when expressed alone and the $\mathrm{N}$ protein from purified $\mathrm{BCV}$ virions. This led us to compare the proteins from both the intracellular and extracellular fractions of infected cells. Cells infected with $\mathrm{BCV}$ were labeled with $\mathrm{EXPR}^{35} \mathrm{~S}^{35} \mathrm{~S}$ for 30 min and either lysed immediately or after a 9 hour chase in medium containing an excess of methionine and cysteine. After the pulse two forms of $\mathrm{N}$ were detected, a $50 \mathrm{kDa}$ and $55 \mathrm{kDa}$ species (Fig 1, lane 4). Both intracellular forms were detected after the $9 \mathrm{hr}$ chase (lane 5). However, when pelleted virions were immunoprecipitated from medium off the cells after the $9 \mathrm{hr}$ chase, only one form of $\mathrm{N}$ was detected in the extracellular virions (lane 6). Labeling with ${ }^{32} \mathrm{P}$ orthophosphate showed that both forms of the intracellular protein were phosphorylated (lane 3). The $50 \mathrm{kDa}$ form from extracellular virions was also phosphorylated (lane 2).

\section{Effect of Calf Intestinal Alkaline Phosphatase on N}

When we labeled for a time shorter than discussed above we noted that the $55 \mathrm{kDa}$ form of $\mathrm{N}$ was detected after the pulse and it appeared to chase to give rise to the $50 \mathrm{kDa}$ form (data not shown). This suggested that some type of processing might be taking place. To begin investigating the nature of the different forms of $\mathrm{N}$, the proteins were treated with calf intestinal alkaline 
Figure 1. Expression of intracellular and extracellular forms of $\mathrm{N}$ in BCV infected BHK cells Infected cells were labeled for 30 min with EXPRE ${ }^{35} S^{35} S$ (lanes 4-6) or ${ }^{32}$ P orthophosphate (lane 3) for $30 \mathrm{~min}$ and the intracellular proteins immunoprecipitated immediately (lane 3-4) or chased for $9 \mathrm{hrs}$ at which time both the intracellular fraction (lane 5) and extracellular virions (lane 6) were immunoprecipitated The intracellular and extracellular fractions in lanes 1 and 2 were immunoprecipitated from BCV infected cells that were labeled for $12 \mathrm{hrs}$ with ${ }^{32} \mathrm{P}$ orthophosphate

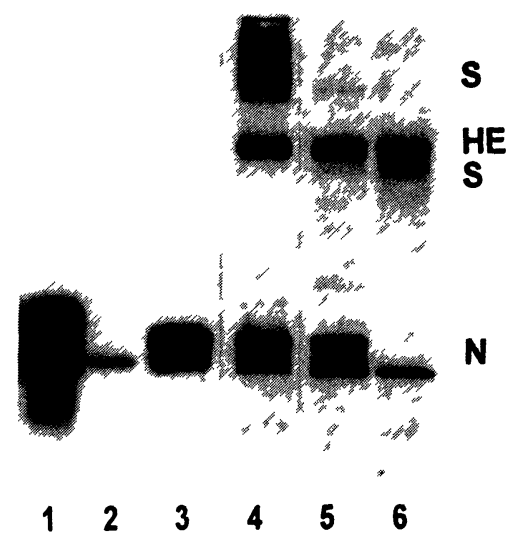

phosphatase (CIAP) after immunoprecipitation The slower migrating $55 \mathrm{kDa}$ form of $\mathrm{N}$ was susceptible to phosphatase treatment ( $\mathrm{F}_{1} \mathrm{~g}$ 2, lane 3 ) However, the faster migratıng intracellular $\mathrm{N}$ and extracellular virion $\mathrm{N}$ were not susceptible to CIAP (lanes 3 and 6)

A higher molecular weight ${ }^{32} \mathrm{P}$ labeled species which may represent an oligomenc form of $\mathrm{N}$ was also detected (lane 2) We and others previously noted such a species in purfied virions, however, the nature and any function of this species remains to be determined ${ }^{67}$

\section{DISCUSSION}

This report shows that multiple forms of the BCV N protein are expressed in virion infected cells The data suggest that the two forms represent different phosphorylation states

Figure 2. BCV infected $\mathrm{HCT}$ cells were labled with ${ }^{32} \mathrm{P}$ orthophosphate for $19 \mathrm{hrs}$ Cell lysates (lanes 1-3), extracellular pelleted virions (lanes 4-6) and unınfected cell lysates (lane 7) were immunoprecipitated with a polyclonal ant1-BCV serum Immune complexes 1solated with protein A Sepharose were divided into three parts and not treated (lanes 1,2 and 7), treated with RNase (lanes 2 and 5) or treated with calf intestınal alkalıne phosphatase (lanes 3 and 6 )
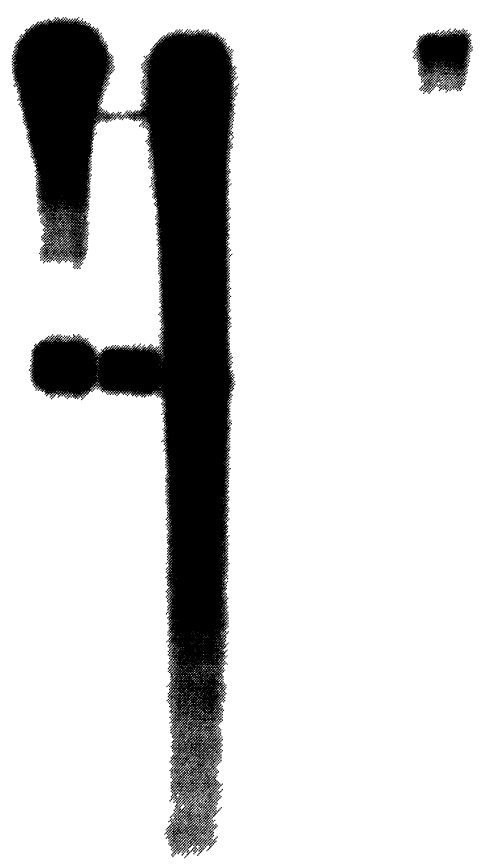
of the protein. This differs from what was previously reported for mouse hepatitis coronavirus (MHV) JHM since only one phosphorylated species was detected in virion infected cells and the mature virion $\mathrm{N}$ comigrated with the phosphorylated intracellular $\mathrm{N}^{8}$. Faster migrating forms of both MHV JHM and A59 have been detected intracellularly; however, these have generally been hypothesized to be cleavage or degradation products of $\mathrm{N}^{7,9}$. MHV $\mathrm{N}$ is phosphorylated at only one or two serines, even though there are a large number of potential sites in the protein ${ }^{10}$. Experiments to determine which sites are phosphorylated on the BCV $\mathrm{N}$ are currently underway.

In contrast to the intracellular pool of $\mathrm{N}$ in BCV infected cells, only one form of $\mathrm{N}$ was present in extracellular virions. It was surprising that the virion form is what appears to be the less phosphorylated form seen in the intracellular fraction. At this point we have not demonstrated which form of $\mathrm{N}$ initially interacts with the RNA to be assembled into the mature virions. However, the data indicate that specificity exists with regard to what is incorporated into virions since only one form is seen in the mature virion. If the more phosphorylated form actually initially interacts with the virion RNA, it is apparently processed in some way to give rise to a form that comigrates with the faster migrating intracellular form. Assuming that two populations of $\mathrm{N}$ molecules are not phosphorylated differently during translation, two types of processing could account for the different forms of $\mathrm{N}$, a dephosphorylation or proteolytic processing. It is possible that the $55 \mathrm{kDa}$ form of $\mathrm{N}$ is converted to the phosphorylated $50 \mathrm{kDa}$ form by dephosphorylation. Data not shown here indicates that the slower migrating form, the $55 \mathrm{kDa}$ species, is initially seen during a short pulse and appears to give rise to the faster migrating form, the $50 \mathrm{kDa}$ species during a chase. Taken together this suggests that proteolytic processing may not be responsible for the faster migrating form seen in the mature virion. If so, dephosphorylation of the $55 \mathrm{kDa}$ species may generate the $50 \mathrm{kDa}$ species.

The functional role of phosphorylation of the coronavirus $\mathrm{N}$ protein is not known; however, it is generally hypothesized that phosphorylation plays a role in the interaction between the protein and the viral RNA. MHV N binds elements within the 5 ' leader sequence found on all mRNAs and the genomic RNA ${ }^{2}$. It was suggested that the interaction may play a role in transcription. Our data also indicates that the BCV N is associated with virion RNAs (Fig. 2 and data not shown). In addition to any role in transcription, the protein must also be involved in assembly. It must specifically encapsidate the genomic RNA and as part of the nucleocapsid, most likely interacts with other viral proteins to assemble the mature virion 11. These multiple roles of $\mathrm{N}$ may be regulated by different phosphorylation states of the protein.

Previously it was shown that MHV JHM N is quickly phosphorylated after synthesis and concomitantly becomes associated with the cell membrane fraction ${ }^{8}$. It was impossible to distinguish multiple phosphorylated forms of $\mathrm{N}$ in the $\mathrm{MHV}^{8}$. Since we detect the two forms of $\mathrm{N}$ in the intracellular fraction of $\mathrm{BCV}$ infected cells this may allow us to study the role(s) this modification may play in replication and assembly.

\section{REFERENCES}

1. Sturman, L.S. and Holmes, K.V., The molecular biology of coronaviruses. Adv. Virus Res. 1983, 28:35-112.

2. Baric, R.S., Nelson, G.W., Fleming, J.O., Deans, R.J., Keck, J.G., Casteel, N. and Stohlman, S.A., Interactions between coronavirus nucleocapsid protein and viral RNAs; implications for viral transcription, J. Virol. 1988, 62:4280-4287.

3. Nakanaga, K., Yamanouchi, K. and Fujiwara, K., Protective effect of monoclonal antibodies on lethal mouse hepatitis virus infection in mice. J. Virol. 1986, 59:168-171. 
4 Stohlman, S A , Kyuwa, S , Polo, J M Brady, D, La1, M M C and Bergmann, C C , Characterization of mouse hepatitis virus-specific cytotoxic $T$ cells derived from the central nervous system of mice infected with the JHM strain J Virol 1993, 67 7050-7059

5 Kıng, B and Brian, D A, Bovine coronavirus structural proteins J Virol 1982, 42 700-707

6 Robbıns, S G , Frana, M F, McGowan, J J, Boyle, J F and Holmes, K V, RNA-binding proteins of MHV detection of monomeric and multimeric $\mathrm{N}$ protein with an RNA overlay-protein blot assay Virology 1986, $150402-410$

7 Hogue, B G, Kıng, B and Brian, D A, Antıgenıc relatıonships among proteins of bovine coronavirus, human respiratory coronavirus OC43, and mouse hepatitis coronavirus A59 J Virol 1984, 51 384-388

8 Stohlman, S A , Flemıng, J O , Patton, C D , and La1, M M C , Synthesis and subcellular localization of the murine coronavirus nucleocapsid protein, Virology, 1983, 130 527-532

9 Cheley, S , and Anderson, R, Cellular synthesıs and modification of murıne hepatitıs virus polypeptides J Gen Virol 1981, 54 301-311

10 Wilbur, S M , Nelson, G W, La1, M M C , McMillan, M, and Stohlman, S A, Phosphorylation of the mouse hepatitis virus nucleocapsid protein, Biochem biophys Res Commun 1986, 141 7-12

11 Sturman, L S, Holmes, K V, and Behnke, J, Isolation of coronavirus envelope glycoproteins and interaction with the viral nucleocapsid, J Virol 1980, 33 449-462 